\title{
The Dimension of Politeness in Speech Acts: Three Pioneering Models
}

\author{
Ayad Hameed Mahmood ${ }^{1}$ Ibrahim Mohammed Ali Murad ${ }^{* 2,3}$
}

${ }^{1}$ English Department, College of Education, University of Diyala, Diyala, Iraq

${ }^{2}$ English Department, School of Basic Education, University of Sulaimani, Sulaimani, Iraq

${ }^{3}$ English Department, College of Education \& Language, University of Charmo, Sulaimani, Iraq

*Corresponding author E-mail: ibrahim.murad@charmouniversity.org

\begin{abstract}
The research in Politeness has received special momentum since the last few decades. Additionally, theorists and pragmaticians have approached it from different perspectives like the social-norm, conversation-maxim, conversation-contact, face-management, discursive (relational work), and others. In this paper, three approaches of politeness are revisited highlighting their characteristics and their drawbacks. These models are chosen to investigate due to their pioneering roles in the domain; they are namely Lakoff's (1973), Leech's (1983), and Brown \& Levinson's (1987). The significance of this paper lies in its focus on the pioneering politeness theories -which are solidly grounded in Grice's Maxims - ,and their approaching fashions in researching politeness. It is worth mentioning that this study is extracted from the literature review of a $\mathrm{PhD}$ dissertation investigating the Kurdish EFL learners' interlanguage pragmatics.
\end{abstract}

Key words: politeness, pragmatics, face threatening act, strategies, speech acts

\section{Introduction}

Traditionally, politeness is generally positioned in the domain of pragmatic research and specifically within the field of communicative competence (Locher 2012). According to Koike (1989, p.279), politeness is believed to be a crucial part of pragmatic competence of the speaker's knowledge besides the rules of appropriateness which together determine how to perform and comprehend speech acts in a social interaction. A postulation as such clearly demonstrates the transparent interrelationship between politeness and speech acts.

Furthermore, the label of politeness does not mark our nonverbal behaviors only, but our talk as well. In daily interactions in any language, to look polite, one is required to commit to a system of social rules which govern the selection of words and shape the forms of sentences. Of course, the social norms of a language are often local in nature and this fact suggests a serious challenge for learners of a second language.

\section{Definitions}


Crystal (2008) defines politeness as "a term which characterizes linguistic features mediating norms of social behavior, in relation to such notions as courtesy, rapport, deference and distance". Crystal's definition suggests that politeness is realized by linguistic resources for the sake of a number of social purposes.

Another technical definition of politeness is what Foley (1997, p.97) conceptualizes as a bunch of strategies used by interlocutors to get smoothly engaged in daily social interactions. In the same vein, in his definition of politeness, Holmes (2001, p.261) conceptualizes politeness as appropriateness in utterances used in the situation and links the level of politeness to the relationship between the interactants postulating that "being linguistically polite involves speaking to people appropriately in the light of the relationship".

Yule (1996, p.60) make links politeness to face, which will be touched upon later, viewing politeness as means used by interlocutors to express awareness of each other's face tuning the social distance between them.

Taking these definitions of politeness into consideration, one may generally conceptualize the term of politeness as appropriateness, gentleness, and tenderness in what is said, by whom, and to whom. Thus, it can be argued that politeness falls within the domain of sociopragmatics, whose notion involves social factors influencing verbal communication aspects or more specifically the linguistic behaviors of interaction participants. It is quite notable that the social nature of relationship between the interlocutors has a vital role in determining the load of politeness in any speech events. Blum-kulka (1987, p.131) views politeness in almost a similar way positing that "the interactional balance achieved between two needs: the need for pragmatic clarity and the need to avoid coerciveness". Needless to say, overdosing or decreasing the amount of clarity or coerciveness may result in impoliteness and consequently pragmatic failure. The complexity in deciding the level of politeness needed in a situation lies in three parameters: a. delimiting the social relationship between the interaction participants, $\mathbf{b}$. being aware of the socio-cultural rules that govern such a relationship in that given community, and c. having an ample knowledge of the linguistic strategies available to express the needed amount of politeness in the language used in the interaction. These parameters help the interlocutors to determine the level of politeness needed in a given social interaction; of course, miscalculating any of them can result in a sociopragmatic failure. A student addressing his teacher, "Will you be silent for a minute!" makes a clear example for such a failure as the expected level of politeness is not loaded in this utterance. 


\section{Politeness and Sociopragmatics}

Apparently, politeness is an inseparable component of almost every social interaction. And it has been demonstrated previously, the "dose" of politeness needed in a conversation is weighed by the three social variable of $\mathrm{D}, \mathrm{P}$, and $\mathrm{R}$, which play a vital role in assessing the weight of FTA. Considering these social parameters is essential for interlocutors to produce effective and appropriate speech acts.

For being of social orientation, the principle of politeness makes the mission of L2 learners more complicated as a considerable part of social norms are cultural specific. Leech (1996, p., 84) touches upon this issue by his classification of politeness into: "relative politeness", which he considers cultural specific, and "absolute politeness" to refer to the universal part of politeness.

The complex part for L2 learners to be aware of in the course of L2 learning is negative politeness. The relativity of politeness, according to Leech (ibid), is attributed to the fact that some behaviors' politeness have fluctuating levels when comparing two communities or more; i.e., what is neutrally polite in English can be too polite or impolite in Japanese, or vise versa. Further, relying on such different concepts, Leech (ibid) stresses that focusing on such phenomena may lead speakers of these communities to stereotype each other to be polite or impolite. As a way out of such misunderstanding, he recommends digging deep in the areas in which language communities have conflicting levels of politeness for, and investigation of such should be conducted within the domain of sociopragmatics.

\section{Estimation of politeness level}

Generally, verbal politeness is normally decided by the appropriateness of what the participants linguistically produce/comprehend in a given social interaction, i.e., what is said is mutually perceived as polite by both the speaker and the addressee (see Watt, 2003). To highlight the dimension of politeness in a speech act performance, speakers resort to structure their utterances in such forms that express gradable extent of politeness like using interrogatives or model verbs. In addition, speakers may adopt specific linguistic strategies in terms of directness or indirectness. Consider the following utterances which share the same proposition:

a. Give me that pen. (quite direct command)

b. I want you to give me that pen.

c. Give me that pen, please. (mitigated by "please")

d. Will you give me that pen?

e. Would you mind giving me that pen, please? (Interrogatively structured request. The addressee's freedom sense raises politeness load ) 
f. Could you give me that pen, please? (Interrogatively structured request. The hesitation sense raises politeness load )

g. I can't reach that pen. (indirect. The speaker's reliance on the addressee's wittiness to get the point raises the politeness load)

h. Sorry to bother you, but I can't reach that pen. (the load is raised by apology)

Apparently, the more direct the utterance is, the less polite the speaker will appear. Also, it is quite clear from the examples above how inseparable the social dimension of politeness and speech acts are. As such, it has been noticed that Grice's (1975) maxims of quality, quantity, relevance, and manner have not amply touched upon this vital dimension in social interactions, which obviously reveals information about the relationship between the interlocutors or among them. This fact has lead scholars like Lakoff (1973), Leech (1983), and Brown \& Levinson (1987) to dive deep in the nature of this relationship besides some other theories that came to existence depicting the impact of politeness on speech acts.

\section{The aim of politeness:}

There is a general agreement that the purpose behind activating the principle of politeness in a communiation is "oiling" the interaction flow and maintaining social relationships by understanding and committing to the conventional obligations and rights that are commonly known in a community by its language users, i.e. it is of social indexing role. Thus, politeness is there in an interaction to smooth communication (Ide 1989, p. 22) or to reduce its "friction" (Lakoff 1975, p. 64).

Politeness dynamically functions as a reducer-like-device for any sort of challenge or confrontation that may occur between a speaker and an addressee (Lakoff 1990, p.34 and Cruse 2000, p.362). In other words, politeness is what the interlocutors linguistically resort to soften the effect of the face-threatening act (FTA) represented in the speech act performed in a given situation. Thus, politeness is commonly referred to as strategic conflict-avoidance and a behavior which is socially acceptable in the view of the language community.

\section{Theorizing Politeness:}

These models of politeness which are investigated in this study are not the only hypotheses in the field, but the foundational and most distinctive ones. Each model has its own contribution that has given it its prolongation. They all approach politeness from English perspective exclusively.

Despite the fact that the establishers of these models have presented their works as models of universal frameworks, Lakoff (1973: 303) admits that "what is polite for me may be rude for you". Lakoff's statement implies the relativity of the principle of 
politeness. Additionally, politeness is cultural specific. However, these models have succeeded in developing some standards for approaching the sociopragmatic aspect of an interaction's participants in any language community.

There are many hypotheses approaching politeness from different perspectives. After reviewing eleven approaches contributing in enriching the domain, Leech (2014, P.54) concludes his review arguing that "in the main these models are hardly in conflict; they all share common ground, and each seems to add something to the overall picture". In this paper, only three models are highlighted due to their weighty contribution in the field.

Due to the flourishing research in politeness, presently there is a journal named Journal of politeness research.

\subsection{Lakoff's model}

In the literature of the theory of politeness, Lakoff (1973) is referred to as the pioneering linguist presenting a model exploring politeness pragmatically. She views politeness as a concept to be "developed by societies in order to reduce friction in personal communication" ( Lakoff 1975,p.64). As such, her view indicates potential negative challenge to occur in daily social interactions and the need for politeness to function as friction-absorber. She arrived at two sets of rules for politeness adopting the cooperative principles of Grice as a theoretical frame to her model. Her first (1973) set was composed of: a. don't impose, b. give options, c. be friendly and her second culturebiased (1990) set included: d. distance, e. difference, and f. camaraderie (Leech, 2014, p.35).

Lakoff makes a connection between politeness and indirectness (Fasold 1990, p.159), and logically this contradicts with her commitment to Grice's maxim of quality which involves clarity which normally suggests directness. This disharmony has led theorists attack Lakoff's model at this point.

Lakoff (cited in Kasper1990, p.211) distinguishes three kinds of politeness: 1. polite behavior, which is manifest when interlocutors adhere to politeness rules, whether expected or not; 2 . non-polite behavior, amounting to non-conforming with politeness rules where conformity is not expected; and 3. rude behavior, where politeness is not conveyed even though it is expected.

\subsection{Leech's model}

One of the marked contributions in theorizing politeness is Leech's (1983) addition of politeness as an extra basic principle to Grice's conversational cooperative principle which is constituted by four maxims: quality, quantity, relevance, and manner(1991, p.28). Similar to Lakoff, Leech (1983), reconsidering Grice's cooperative principle, 
suggests politeness as a necessary dimension to fill the gap in Grice's maxims. In other words, Leech (ibid, p.82) views the cooperative principle to be essential in forming what is said to perform a speech act whereas politeness principle gets active to tune the social relationship between the interlocutors in terms of the needed level of politeness to keep the sense of friendliness flowing during the conversation; no politeness, no successful communication. His suggestion is based on viewing that the cooperative principle is sometimes violated for the sake of politeness. One of the examples he gives is breaching the maxim of quality for the sake of irony:

- A: Geoff has just borrowed your car.

- B: Well, I like THAT! (polite but not true) (ibid, p.83)

Reviewing Leech's model of politeness, Spencer-Oatey \& Žegarac (2010, p.76) mention that "Leech proposes a set of 'politeness maxims' such as the 'modesty maxim' and the 'agreement maxim', which operate in conjunction with the cooperative maxims". It seems that in his set of maxims, Leech is inspired by the act of face in the point of underlining the role of self and other to govern the interaction. The maxims of Leech (1983) are six: tact, generosity, approbation, and modesty. They involve, on the one hand, minimizing both praise of self and disagreement between self, and, on the other hand, maximizing both dispraise of self and agreement between self and other. The significance of politeness principle to Leech is clearly spotted in its vital role in shaping and wording our utterances in our daily interactions to either maintain communication or impede any offence that might be felt by the addressee.

Leech (ibid, p.104) categories illocutionary acts in four sets:

(a) Competitive: The illocutionary goal competes with the social goal; e.g. ordering asking, demanding, begging;

(b) Convivial: The illocutionary goal coincides with the social goal; e.g. offering, inviting, greeting, thanking, congratulating;

(c) Collaborative: The illocutionary goal is indifferent to the social goal; e.g. asserting, reporting, announcing, instructing;

(d) Conflictive: The illocutionary goal conflicts with the social goal; e.g. threatening, accusing, cursing, reprimanding.

And in the light of the illocutionary acts above, Leech (ibid) identifies the nature of politeness needed in the situation. As the competitive acts suggest imposition on the addressee, he labels the politeness needed here negative politeness whereas convivial acts involve positive politeness due to their courteous nature. On the other hand, no politeness is detected in the third and the fourth types of acts as the former is neutral and 
the latter is offensive by nature. This categorization of politeness of Leech is similar to Lakoff's classification of politeness mentioned previously.

The match between politeness and illocutionary acts has been criticized for that it is not comprehensive since it does not cover speech acts like refusal and complaining. Additionally, it is accused of having bias in favor of western culture (Al-Hindawi \& AlKhazaali 2016, p.1541) and this entail that it fails to work crosslinguistically as well as crossculturally.

\subsection{Brown \& Levinson's model}

A more sophisticated theory of politeness was developed by Brown and Levinson in 1978 which later appeared in a least-gaps version in 1987. This model is considered as the most influential work in the domain to date (Leech 2007; Locher 2012). "It tries to explain the impact of social factors on people's use of language" (ibid). In this theory, politeness is basically represented by the social value or the self-image that one claims for himself/herself when communicating with others. Brown and Levinson, following Goffman (1967), call this value or public self-image "face", which is forked into positive and negative. By the positive face, they mean the interlocutor's desire to have an appreciated and approved self-image or personality whereas the term negative face is used to indicate one's desire to be free of any action or imposition and be away from any distraction or disturbance (Brown \&Levinson 1987, p.61; Leech 2104, p. 24; and Spenser-Oatey \&Žegarac) 2010, p.76).

Politeness in this theory is realized to be essential in a social interaction as Brown \& Livenson (1978/1989) view most speech acts threaten either the speaker's face or the addressee's face. The role politeness gets effective in redressing the positive and negative faces. The speaker is normally keen on assessing the loss of face in the interaction and according to which he/she chooses the appropriate strategy whether to be bold and express the intended message directly, or be polite and put it indirectly or mitigate it (Locher 2012).

Like other models in the field, Brown \& Livenson theory has been criticized for several points. One of the issues raised against this work is that its universality is questionable; it is argued that its framework is western bias and the claim of universality needs empirical studies in many parts of the world to confirm the patterns of politeness in different culture. Another criticism is that in the literature of politeness theory places no stress on impoliteness arguing it is incorporated with politeness (LoCastro, 2012). In spite of these drawbacks and few others, Brown \& Livenson's politeness principle is still the most prominent and popular model in the field and provides a reasonable system 
which can define the patterns of communicative competence of any language community.

\subsubsection{Face threatening act (FTA)}

In the theory of politeness of Brown and Livenson, both speakers and hearers have face wants and that the various sorts of face are open to different threatening acts targeting the two parties (speakers and hearers), for instance, threatening the hearer's negative face by requests, commands, suggestions, or threats. However, what may threaten the hearer's positive face can be acts like offers and promises.

On the other hand, what threaten the speaker's negative face are acts like accepting offers or apologies, and expressing thanks or excuses whereas acts like apologies and confessions of responsibly are typical instances of the acts that threaten a speaker's positive face. Other types of face threatening acts (FTA) are covered in this theory but not dealt with as they are beyond the interest of this study (Brown \& Livenson 1987, pp. 65-67).

\subsubsection{The weight of (FTA)}

Further, every face-threatening act (FTA) gets loaded by certain socially oriented factors which Brown \& Levinson refer to as weight. To measure the weight of a facethreatening act, three social variables are considered: distance, power, and ranking of imposition (also called rank). (ibid, 74-76)

The social distance (D) between the interaction participants, the power (P) or the position that each participant has in the society or the age of each, and the ranking (R) of sensitivity or the seriousness that the topic (or the speech act) imposes on the addressee, all these factors play role in determining the potential (FTA) and the weight of politeness needed in the context. Brown \& Livenson (ibid, p.76) present these variables in relation with the weight of politeness in this formula: $\mathbf{W x}=\mathbf{D}(\mathbf{S}, \mathbf{H})+\mathbf{P}(\mathbf{H}, \mathbf{S})+\mathbf{R x}$. (S stands for speaker and $\mathrm{H}$ for hearer)

Normally, the three factors of D, P, and R are interrelated. Also, they are not the sole parameters as "they subsume others (status, authority, occupation, ethnic identity, friendship, situational factors, etc.)" (ibid, 80).

Linguistically, politeness is realized by a number of strategies, which are dealt with in the next sections. Choosing a particular strategy depends on social environment in which the speech act is performed: who is the addressee, the nature of the social relationship between the speaker and the addressee, and the nature of the topic of the interaction. To sum it up, the strategy of politeness is correlated with the three social variables mentioned above. 


\subsubsection{FTA strategies}

Brown \& L (1987) present a set of strategies which conversational partners may resort to when performing a speech act. The speaker's choice of a strategy is pragmatically oriented - mostly to mitigate the threat that the act can cause to the addressee's face. Being complicated, the strategies require rationality to be practiced as the two theorists assume (ibid, p.68).

The strategies, when doing FTA, are mainly divided in two parts: on record and off record. The first category is forked into either doing the action baldly, or doing it with redressive action, which in its turn is of two types: positive politeness and negative politeness. The second category is of no specific form due to the obfuscatory of the speech act as the utterance carries more than one interpretation to the addressee and then vague illocutionary force. To put it straightforward, the second category of FTA strategies involves indirectness in the utterance used to convey the message by the speaker; therefore, the strategy may come in the form a metaphor, an irony, a hintgiving, an exaggeration, a euphemism, contradiction, or others (ibid, p.69).

\subsubsection{Bald on record strategies:}

When the speaker performs the speech act straight to the point, clearly, and without uttering anything that may redress the threat of the act or save the addressee's face, then he/she is said to enact bald on act strategy. An example of this is using a command pattern to ask the addressee to do something:

- Listen to me.

- Look out!

- You can't speak loudly here.

According Brown \& Livenson (ibid) using this strategy is common when the speaker fears no counterattack or retribution from the addressee in situations like urgency, danger, and vast superiority of the speaker over the addressee as the examples above suggest respectively. Thus, the clear and perspicuous nature of what is uttered makes it a prominent trait of this strategy.

\subsubsection{On record with redressive action:}

This strategy also involves direct and clear formation of the speech act, but characterized with what softens the threat of the act on the addressee's face or as Brown \& Livenson (ibid, p.70) put it "gives face" to the addressee, i.e. to avoid the damage that FTA may cause. And this goal is realized by choosing one of these two forms: positive politeness and negative politeness; each is determined by the face targeted by the speaker.

\subsection{Positive politeness strategy}


Positive politeness strategy is followed by a speaker who intends to attend the positive face wants of the addressee by expressing intimacies, support, or any similar actions that help in making the addressee feel respected and liked (ibid). That is, "the speaker appears to be friendly and helpful" (LoCastro, 2012, p.139), or as summarized by Brown \& Livenson (1987, p.72) positive politeness is "to satisfy the hearer's positive face" and the speaker attempts to make his desires similar to the addressee's. Therefore it is "approach based".

There are a number of strategies that can be listed under positive politeness, like complimenting, offering, promising, joking, agreeing, using in-group identity markers, and some others (LoCastro, 2012, p.141). The following are some examples realizing strategies of such:

- I adore the tea you make. (compliment)

- I'll be there to help you with it. (promise)

- Give me your UFO for an hour. (joke)

- Definitely true, we can do it right now. (agreement)

- Come on, brother, just give it a try. (in-group identity marker)

\subsection{Negative politeness strategy}

The label Brown \& Livenson (1987) suggest for the orientation of this strategy is "avoidance-based" as with this strategy the speaker understands the negative face wants of the addressee and attempt not to disturb his/her freedom of action. Accordingly, the speaker uses linguistic terms that indicate the speaker's intention "to disturb the addressee as little as possible" (LoCastro, 2012, P.140).

This strategy is realized by various forms like apologizing (Excuse me, can I sit here?); being pessimistic (I know you can't afford any more time to finish this, can you?; being conventionally indirect (Could you lend your pen?; giving deference (You are absolutely welcome to join us); impersonalizing the act (These papers need to be reprinted in an hour), and some others.

\subsubsection{Off-record strategy:}

Indirectness and implication are the main characteristics of this strategy. Of course such nature target the addressee's ability to interpret the received message and this ability generally relies on his/her pragmatic knowledge shared with the speaker. The trait of this strategy is that it attends the negative face of the addressee (Brown \& Livenson, 1987). Examples of such strategy are as follows:

- Your question is a piece of cake. (metaphor)

- A: You're invited to my party tonight.

B: You know, tomorrow is our project delivery deadline. (hint) 
- Don't you think it's getting cold? (rhetorical question) Off-record politeness strategy is viewed by El-Samir (2014 p.34) to imply imposition on the addressee. Her judgment must be built on the fact the structure of an utterance in this strategy requires the addressee to figure the intended message of the addresser.

\section{Conclusions}

The three models agree on politeness to have the function of keeping the ball of a social interaction rolling smoothly. Despite the fact that they could not avoid the dominance of West-European culture specificity, they provide feasible framework for assessing the sociopragmatic performance of EFL learners. Additionally, Leech and Brown \&Livenson's models may potentially be open for modification to apply to other languages of cultures other than West-European culture. The three models have ignored impoliteness in their literature, which made modern hypotheses to appear to investigate it. Indirectness is correlated with politeness in the view of the three models. What the three models are equally criticized for is that they all approach politeness from the speaker's perspective and no reference to the addressee's. Comparing the models to each other, Brown \& Levinson's model is more workable and practical as it is not strictly confined to a limited number of speech acts.

\section{References}

1. Al-Hindawi, F. H. \& Al-Khazaali, M. R., 2016. A Critique of Politeness Theories. Theory and Practice in Language Studies, 6(8), pp. 1537-1545.

2. Blum-kulka, S., 1987. Indirectness and Politeness in Requests :Same or Different? Journal of Pragmatics, 11(2), pp.131-46.

3. Brown, P. \& Levinson, S. C, 1987. Politeness: Some universals in language. Cambridge: Cambridge University Press.

4. Cruse, A., 2000. Meaning in Learning: An Itroduction to Semantics and Pragmatics. oxford: oxford university press.

5. Crystal, D., 2008. A Dictionary of Linguistics and Phonetics. 6th ed. Malden: Blackwell Publishing.

6. El-Samir, S.F., 2014. Politeness: A Socio- Pragmatic Study. Journal of the College of Languages, (28), pp.1-37.

7. Fasold, R., 1990. The Sociolinguistics of Language. Cambridge: Basil Blackwell.

8. Foley, W., 1997. Anthropological Linguistics: An introduction. Malden: Blackwell Publishers.

9. Grice, P., 1991. Studies in the Way of Words. 1st ed. USA: Harvard University Press.

10. Holmes, J., 2001. An Introduction to Sociolinguistics. Edinburgh: Longman. 
11.Kasper, G., 1990. Linguistic Politeness: Current research issues. Journal of Pragmatics, 14(2), pp.193-218.

12.Lakoff, R.T., 1973. The Logic of Politeness; or minding your p's and q's. Papers from the ninth regional meeting of the Chicago, pp.292-305.

13.Lakoff, R.T., 1975. Language and Women's Place. New York: Harper \& Row.

14.Lakoff, R.T., 1990. Talking Power: The Politics of Language in our Lives. New Yourk: Basic Books.

15.Leech, G., 2007. Politenes: Is there an East-West divide? Journal of Politeness Research, 3(2), pp.167-206.

16.Leech, G., 2014. The pragmatics of politeness. 1st ed. oxford: oxford university press.

17.LoCastro, V., 2012. Pragmatics for Language Teachers. New York: Taylor \& Francis.

18.Locher, M.A., 2012. Politeness research from past to future, with a special focus on the discursive approach. In Amaya, L.F..L.M..M.R..C. New perspectives on (im)politeness and interpersonal communication. Cambridge: Cambridge Scholars Publishing. pp.1-22.

19.Spencer-Oatey, H. \& Žegarac V., 2010. Pragmatics. In N. Schmitt, ed. An Introduction to Applied Linguistics. 2nd ed. London: Hodder Education. pp.70-88. 20.Watts, R., 2003. Politeness. Cambridge: Cambridge University Press.

21.Yule, G., 1996. Pragmatics. Oxford: Oxford University Press.

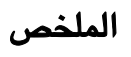

لقد اكتسب البحث في مبدأ التأدّب في التخاطب زخماً خاصاً في العقود القليلة الماضية فضلاً عن تناول المنظّرين وعلماء التداولية للتأدّب والتهذيب في القول من منظورات متعددة مثل الاجتماعي المعياري ، والمبدأ الخطابي ، والتواصل الحواري، وادارة الوجه

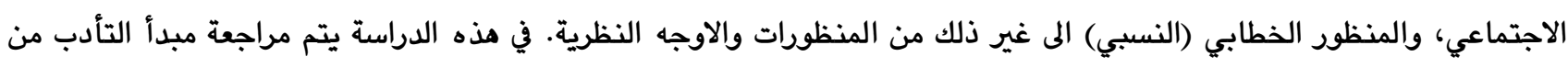

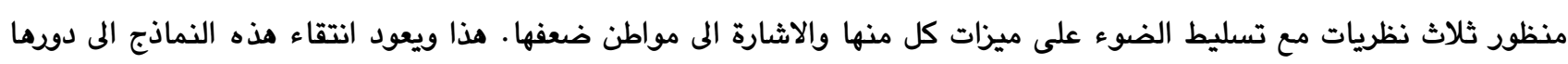

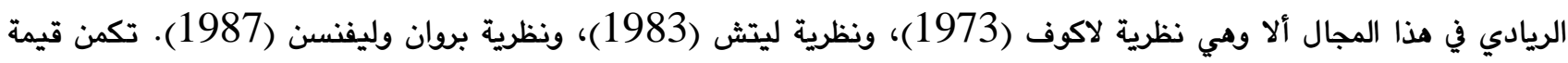
الدراسة هذه في تركيزها على ريادية هذه النظريات- التي استندت في اطرها النظرية الى مبادئ غرايس (Grice Maxims ) -

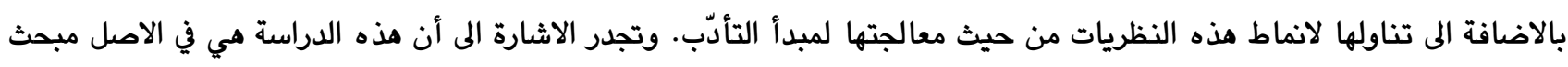
مستلّ من اطروحة دكتوراة قيد الانجاز تتناول الأداء التداولي للطلبة الكورد من متعلمي اللغة الانكليزية كلفة اجنبية. 